\title{
Letters
}

\section{The Uses and Limitations of Trueswell}

\section{To the Editor:}

I was somewhat astonished at the vehemence of Richard Trueswell's rejoinder (CむRL, Sept. 1979) especially as it seemed to make no reference to that particular aspect of his work of which I was most critical. I would like to close my side of the discussion by commenting on three matters.

First, I did not claim that Trueswell's basic procedure is fallacious. On the contrary, I think it is a major contribution, perhaps the best and most practical technique we have for finding out from circulation statistics how a collection is being used. If I had not thought that his procedure was both sound and useful, I would not have adopted it for my own research.

But a procedure is one thing; the drawing of conclusions after using the procedure may be something else again. This brings me to the second matter for comment: Trueswell's stance with respect to library policies. In general, it is true that we should not hold researchers responsible for the use that others make of their work. We should not blame Robert Ardrey on Konrad Lorenz, or Herman Kahn on Einstein. But when a researcher knows that his or her work is being repeatedly cited in professional literature in support of a certain policy, the researcher probably has a responsibility to take a position on whether or not the use of the conclusions seems appropriate. If the researcher does not do so, onlookers are probably justified in assuming that silence implies assent. I had, of course, read Trueswell's disclaimer of any particular policy recommendations; but by publishing his article under the title "Growing Libraries: Who Needs Them? A Statistical Basis for the No-Growth Collection," he has made his research vote in a sweeping and emphatic way on the basic policy issue in question. Surely, my paraphrases do not seriously overstate the implications of that title.

The third matter is my specific use and criticism of Richard Trueswell's work. The article that I referred to from Gore's Farewell to Alexandria collection, the title of which is quoted above, is Trueswell's most recent statement of his procedures and results as they relate to book collections. If my criticism had been directed at omissions, his complaint that I have not cited other articles would probably have merit. But since I was commenting on what seems to me a mistake in what he did say, it still seems reasonable to treat his most recent statement as authoritative.

The mistake or fallacy that I was commenting on was not a matter of data or sampling procedure, but of analytical method. And the basic point of a preliminary study should be to get such methods straightened out.

Once again, my criticism is directed at the claim, developed on pages $84-86$ of Farewell to Alexandria, that a core collection consisting of those books that have circulated since the established cutoff date can be expected to satisfy 99 percent of circulation requirements. More precisely, the fallacy consists in establishing the core in such a way that all books that have never circulated are excluded from it, regardless of how recently they were obtained. Trueswell is saying, in effect, that there is a 99 percent probability that the next book to circulate will have circulated at least once since the established cutoff date.

What he is justified in saying is, There is a 99 percent probability that the next book to circulate will have circulated or been added to the collection since the cutoff date. This is more than a lapse of language, it must be noted, since it is confining the core to those books that have actually circulated that leads to the famous and mistaken claim that more than half the collection could be disposed of with only a 1 percent decline in user satisfaction.

This point that I have criticized is a rather important one from the standpoint of the current debate on library policy, but a 
very small one from the standpoint of judging the value of Trueswell's contribution. I will close by apologizing for a tone that perhaps implied a fuller condemnation than I intended. I would be truly disturbed if I thought that the effect of my comments would be to discourage librarians from exploring and using the Trueswell procedure.-Seymour H. Sargent, Library Science Department, University of Wisconsin-Oshkosh.

\section{In Search of New Horizons}

To the Editor:

That is a strange review of my In Search of New Horizons in the July issue of College \& Research Libraries.

Every standard reference book that I have consulted states that Admiral Robert Peary reached the North Pole on April 6, 1909 , and spent thirty hours there planting flags and making observations. I wonder if Madden believes in the thoroughly discredited Dr. Cook story.

As to the question of whether the ALA is a proper publisher for such a book, it should be noted that In Search of New Horizons is a book about books, in the same category as Books That Changed the World. Even in a profession increasingly crazed about automation and computers, I assume that the ALA is still somewhat bookoriented.
I can offer no defense of my writing style, though it doesn't seem to have stood in the way of my books selling in the hundreds of thousands of copies, and a well-known science writer, David Dietz, described it as having "clarity, force and charm."-Robert B. Downs, Dean of Library Administration Emeritus, University of Illinois at UrbanaChampaign.

\section{Response}

To the Editor:

Standard reference works have the unfortunate habit of perpetuating the mistakes of their predecessors, as well as inventing new ones, such as the New Columbia Encyclopedia's identification of Franz Ferdinand as a grandnephew of Franz Joseph. A dispassionate reading of the literature of polar exploration establishes that neither Peary nor Cook reached his goal, despite the claims in their self-serving narratives.

The fact that In Search of New Horizons is a book about books, which I discerned at first reading, does not cause me to modify my doubt concerning the appropriateness of its publication by the American Library Association.

I am happy that hundreds of thousands of Dean Downs' books have been sold to readers who have a taste in style different from mine.-Henry Miller Madden, Fresno, California. 


\section{NEW TITLES \\ FROM GREENWOOD PRESS}

\section{COGENT COMMUNICATION:}

Overcoming Reading Overload.

by Charles $\mathrm{L}$. Bernier and

A. Neil Yerkey.

(Contributions in Librarianship and Information Science, No. 26).

xii, 280 pages, app., figs.

LC 78-73794. ISBN 0-313-20893-X.

\section{$\$ 19.95$}

A comprehensive synthesis of thought on the problem of reading overload as well as its proven solution. Discusses methods of selection, evaluation and condensation for dealing with the problem.

\section{GUIDE TO INFORMATION \\ SCIENCE.}

by Charles H. Davis and

James E. Rush.

December, 1979. Approx. 352 pages.

LC 78-75240. ISBN 0-313-20982-0.

The first up-to-date book to combine the technical sophistication necessary to explore this complex field with a clarity and readability that make the Guide a perfect introduction for the nonspecialist.
THE LIBRARIAN'S PSYCHOLOGICAL COMMITMENTS: Human

Relations in Librarianship.

by Florence E. DeHart.

(Contributions in Librarianship and Information Science, No. 27).

xiii, 209 pages.

LC 79-7059. ISBN 0-313-21329-1.

$\$ 18.95$

Will help any librarian or library student better understand the personal, human demands of the profession by providing a conceptual framework for applying behavioral skills to librarianship.

"... should be required reading for library personnel officers."

-Booklist

\section{RECENTLY PUBLISHED}

INTERNATIONAL AGRICULTURAL LIBRARIANSHIP: Continuity and Change.

Edited by Alan Fusonie and Leila Moran.

Proceedings of an International Symposium held at the National Agricultural Library November 4, 1977.

ix, 127 pages, table, figs.

LC 78-67916. ISBN 0-313-20640-6.

$\$ 18.95$

\section{REQUIEM FOR THE CARD CATALOG:}

Management Issues in Automated Cataloging.

Edited by Daniel Gore, Joseph Kimbrough and Peter SpyersDuran.

xvi, 200 pages.

LC 78-7129. ISBN 0-313-20608-2.

$\$ 17.50$

EVALUATING INFORMATION RETRIEVAL SYSTEMS: The Probe Program.

by Eva L. Kiewitt.

xviii, 168 pages, figs., tables.

LC 78-55322. ISBN 0-313-20521-3.

$\$ 15.95$

ACADEMIC RESEARCH AND LIBRARY RESOURCES: Changing Patterns in America.

by Charles B. Osburn.

xx, 187 pages, tables.

LC 78-20017. ISBN 0-313-20722-4.

$\$ 18.95$

Request your own free copies of Greenwood Press catalogs and brochures. Check the ones you wish to receive:
$\square$ Library Science Catalog
$\square$ Catalog of New Fall Books, 1979
Contributions in Librarianship and Information Science
$\square$ New Directions in Librarianship

Name

Library or Institution

Address

City State Zip (please) 


\section{Important References from K.G. Scurt}

INTERNATIONAL BIBLIOGRAPHY

OF STANDARDIZED

VOCABULARIES

Initiated by Eugen Wuster

Comp. by Helmut Felber,

Magdalena Krommer-Benz

and Adrian Manu

1978. 2nd ed. ISBN 0-89664-075-2

540 p. $\$ 64.50$ Hard Cover

This work contains bibliographical data published by all standardization associations of the world. Included are details about vocabularies edited by organizations issuing terminological recommendations. Eight thousand entries are listed.

\section{INTERNATIONAL DIRECTORY}

OF MEDIEVALISTS

Ed. by Centre National de la Recherche Scientifique, Paris 1979. 6th ed. 2 vols. Volume 1 ISBN 0-89664-046 426 p. $\$ 60.00$ (Vol. 1 Only) Hard Cover (Vol. 2 to be published end of 1979)

ISBN 0-89664-246-1 ca. 500 p. Pre-publication price for 2-volume set $\$ 99.00$

A complete and comprehensive bio-bibliographical guide containing more than 6,000 entries. Listed are specialists on medieval history throughout the world: anthropologists, archaelogists, cartographers, church historians, philosophers, music historians, genealogists, numismatists and sociologists. A subject index is also included. The bibliography lists works published since the last edition was published five years ago.

\section{PUBLISHERS' INTERNATIONAL DIRECTORY}

8th Revised Edition

Ed. by Michael Zils

1979. ISBN 0.89664-100-7

970 p. $\$ 129.00$ Hard Cover

An indispensable tool for locating the resources your library needs. This directory lists some 37,000 active publishers in Europe, the Americas, Asia and Oceania. Each entry gives the publisher's name, address, publisher specialties and ISBN prefix. The directory also includes a convenient International ISBN Publishers' Index.

\section{BOOKS IN OTHER LANGUAGES Comp. Leonard Wertheimer Co-published with the Canadian Library Association Distributed by K.G. Saur Publishing 1979. 4th Edition \\ ISBN 0-89664-147-3 \\ 144 p. $\$ 15.00$ Soft Cover}

As a guide to the librarian looking for foreign language titles, this publication is an invaluable source of information. It lists reference aids for finding these books, as well as suppliers to help the librarian acquire them with a minimum of effort. Prices of the reference aids, in addition to the complete addresses of both publishers and suppliers, are given.

All prices subject to change without notice. Prices do not include postage and handling charges. Orders outside USA please add US $\$ 1$ for postage and handling. Payable in US funds on US banks only. Orders from individuals should be prepaid.

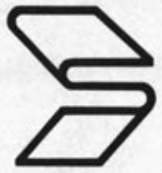

K.G. SAUR PUBLISHING INC.

NEW YORK· MÜNCHEN ·LONDON·PARIS

175 FIFTH AVENUE, NEW YORK, NEW YORK 10010

TELEX 238386 KGSP UR (212)-477-2500 